\title{
Immunoprecipitation, Immunoblotting, and Immunocytochemistry Studies Suggest That Glutamate Receptor $\delta$ Subunits Form Novel Postsynaptic Receptor Complexes
}

\author{
Ebrahim Mayat, Ronald S. Petralia, Ya-Xian Wang, and Robert J. Wenthold \\ Laboratory of Neurochemistry, NIDCD, NIH, Bethesda, Maryland 20892
}

An antibody was made to a C-terminus peptide of the glutamate receptor $\delta 2$ subunit and used to study the distribution, biochemical properties, and developmental expression of the $\delta$ receptor in rat brain. The antibody recognizes both $\delta 1$ and $\delta 2$ but not AMPA, kainate, NMDA, and mGluR1 $\alpha$ glutamate receptor subunits based on Western blot analysis of transfected HEK-293 cells. Western blot analysis of brain showed a single immunoreactive band, migrating at $M_{r}=114,000$. Immunoprecipitation of detergent-solubilized cerebellar membranes was done to determine if $\delta$ is associated with other glutamate receptor subunits and if it binds any of the common excitatory amino acid ligands. Based on results of these studies, AMPA, kainate, NMDA, and mGluR1 $\alpha$ subunits do not coassemble with $\delta$ subunits, and ${ }^{3} \mathrm{H}$-glutamate, ${ }^{3} \mathrm{H}$-AMPA and ${ }^{3} \mathrm{H}-k a i n a t e$ do not bind to the $\delta$ receptor complex. Western blot and immunocytochemical analyses showed marked expression of $\delta$ in the cerebellum while lower levels were detected in other regions of the brain. A dramatic increase of $\delta 1 / 2 \mathrm{im}$ munoreactivity was observed in the cerebellum between the ages of 10 and $15 \mathrm{~d}$ postnatal. Light and electron microscopy, respectively, demonstrated dense immunostaining in Purkinje cells and in postsynaptic densities of the adult parallel fiber-Purkinje spine synapse. The prominent $\delta 1 / 2$ immunoreactivity found in the parallel fiber-Purkinje spine synapse, and the temporal correlation of the development of this synapse with the major increase in $\delta 1 / 2 \mathrm{im}$ munoreactivity, suggest a major functional role for the $\delta$ subunits in cerebellar circuitry.

[Key words: ligand binding, Purkinje cells, parallel fibers, cerebellum, long-term depression, metabotropic glutamate receptors]

Glutamate is the major excitatory amino acid in the mammalian CNS (review by Monaghan et al., 1989). Glutamate receptors in the CNS can be classified broadly into metabotropic and ionotropic receptors. Metabotropic glutamate receptors (mGluRs) are coupled to phosphoinositide and/or cAMP metabolism while ionotropic glutamate receptors (GluRs) contain integral, cation-

\footnotetext{
Received July 11, 1994; revised Sept. 28, 1994; accepted Oct. 12, 1994.

We thank Drs. Peter Seeburg, Hilda Lomeli, Stephen Heinemann, and Shigetada Nakanishi for supplying cDNA clones. We are grateful to Dr. Masayoshi Tachibana for helpful suggestions in preparing the manuscript.

Correspondence should be addressed to Ebrahim Mayat, Laboratory of Neurochemistry, Building 36, Room 5D-08, NIDCD-NIH, Rethesda, MD 20892. Copyright (C) 1995 Society for Neuroscience 0270-6474/95/152533-14\$05.00/0
}

specific ion channels (for a recent review, see Hollmann and Heinemann, 1994). According to pharmacological and subsequent binding studies, GluRs were classified into three main subtypes: the NMDA, $\alpha$-amino-3-hydroxy-5-methyl-4-isoxazole propionic acid (AMPA), and kainate (KA) receptors (for reviews, see Monaghan et al., 1989; Watkins et al., 1990; Young and Fagg, 1990). In the last 5 years, cloning studies have led to the characterization of multiple subunits which comprise each of the three GluR subtypes (for reviews, see Nakanishi, 1992; Sommer and Seeburg, 1992; Hollmann and Heinemann, 1994). The AMPA receptor has four subunits, GluR 1-4, or GluR-A to -D (Hollmann et al., 1989; Boulter et al., 1990; Keinänen et al, 1990; Nakanishi et al., 1990; Sakimura et al., 1990). The kainate receptor has five subunits, GluR5-7 and KA1 and KA2 (Bettler et al., 1990; Boulter et al., 1990; Egebjerg et al., 1991; Herb et al., 1992; Lomeli et al., 1992; Sakimura et al., 1992; Werner et al., 1992). The NMDA receptor has five subunits, NR1, NR2A, -2B, -2C, and -2D (Kutsuwada et al., 1992; Meguro et al., 1992; Monyer et al., 1992).

In addition to these three major classes of functional GluRs, a number of other subunits which are structurally related to other GluRs but with, as yet, no demonstrable function have been identified. These include the kainate binding proteins (KBPs), which were among the first members of the GluR family to be cloned (Gregor et al., 1989; Wada et al., 1989) and appear to be expressed only in lower vertebrates, and the more recently identified $\delta$ receptor in mammalian brain (Yamazaki et al., 1992; Araki et al., 1993; Lomeli et al., 1993). Two apparent subunits of the $\delta$ receptor have been identified in both mouse and rat. $\delta 1$ and $\delta 2$ share $56 \%$ amino acid identity, but have low homology with other GluR subunits (18-25\% identity). 82 mRNA is expressed predominantly in cerebellar Purkinje cells (Araki et al., 1993; Lomeli et al., 1993), while $\delta 1 \mathrm{mRNA}$ is expressed lightly throughout the brain, with higher expression in developing brain. The most distinguishing characteristic of the $\delta$ subunits, however, is their apparent lack of ion channel activity when expressed alone, together, or in combination with other GluR subunits. This raises the possibility that the $\delta$ subunits are nonfunctional in brain or that additional subunits are required to form functional receptor complexes. To further characterize the $\delta$ receptor, we have developed an antibody selective for the $\delta 1$ and $\delta 2$ subunits. Such antibodies can be applied to determining the light and ultrastructural localization of the $\delta$ subunits, probing their relationships with other glutamate receptor subunits, and screening their possible ligand binding properties, all of 
which may provide clues concerning the function of this putative receptor complex.

\section{Materials and Methods}

Antibody production and characterization. A synthetic peptide (QPTPTLGLNLGNDPDRGTSI) corresponding to the carboxyl terminus 20 amino acids of the rat glutanate $\delta 2$ receptor subunit (Lomeli et al., 1993) was prepared commercially. Following conjugation to bovine serum albumin (BSA) using glutaraldehyde, and injection into rabbits according to the protocol used for making antibodies to the AMPA receptors described by Wenthold et al. (1992), the antibodies were affinity purified using the peptide attached to activated $\mathrm{CH}$ Sepharose $4 \mathrm{~B}$ (Pharmacia LKB Biotechnology, Piscataway, NJ) as described (Petralia and Wenthold, 1992; Wenthold et al., 1992).

The $\delta 1$ and $\delta 2$ cDNA clones inserted into the eukaryotic pRK5 plasmid vectors were kindly provided by Drs. P. Seeburg and H. Lomeli, University of Heidelberg, while the cDNA clones of the other glutamate subunits used in this study were kindly supplied by Drs. S. Heinemann, Salk Institute, S. Nakanishi, Kyoto University, and P. Seeburg. The cDNAs were transfected into human embryonic kidney cells (HEK-293) by the calcium phosphate-DNA precipitation method with commercially obtained reagents (Specialty Media, Inc., Lavalette, NJ). Cells were harvested $48 \mathrm{hr}$ after transfection and washed with $50 \mathrm{~mm}$ Tris- $\mathrm{HCl}, \mathrm{pH}$ 7.4 .

Electrophoresis and immunoblotting. Sodium dodecyl sulfate-polyacrylamide gel electrophoresis (SDS-PAGE) was carried out according to the method of Laemmli (1970) using gels $8 \mathrm{~cm}$ in length with acrylamide gradients of 4-20\%. Proteins were transferred to nitrocellulose membranes as described by Towbin et al. (1979). Membranes were treated overnight with $5 \%$ nonfat dry milk in Tris buffered saline-

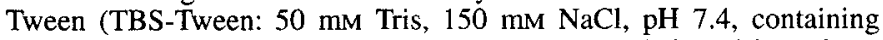
$0.05 \%$ Tween 20 ). Antibodies were used at $1.5 \mu \mathrm{g} / \mathrm{ml}$, and bound antibody was detected using either the alkaline phosphatase detection system (Kirkegaard and Perry Laboratories, Inc., Gaithersburg, MD) or the chemiluminescence detection system (New England Nuclear, Boston, MA). Prestained standards from GIBCO-Bethesda Research Labs were myosin, phosphorylase b, BSA, ovalbumin, carbonic anhydrase, $\beta$-lactoglobulin, and lysozyme, migrating at $M_{r}=203,000,105,000,71,000$, $44,000,28,000,18,000$, and 15,000 , respectively. Molecular mass was estimated using unstained standards, myosin $(200 \mathrm{kDa}), \beta$-galactosidase $(116 \mathrm{kDa})$, phosphorylase $\mathrm{b}(97 \mathrm{kDa})$, BSA $(66 \mathrm{kDa})$ and ovalbumin (45 kDa), obtained from Bio-Rad (Richmond, CA).

Immunoprecipitation. Membranes were prepared from adult rat cerebellum and solubilized with Triton $\mathrm{X}-100$ as previously described (Wenthold et al., 1992). Immunoprecipitation of receptors from brain was then carried out as follows. Anti- $\delta 1 / 2$ antibody $(5-10 \mu \mathrm{g})$ was incubated with Triton X-100 solubilized cerebellar membranes at $4^{\circ} \mathrm{C}$ for $1.5 \mathrm{hr}$. Protein A-agarose was then added to the incubation mixture and left to incubate for an additional $1.5 \mathrm{hr}$. The resin was pelletcd by centrifugation ( $3000 \mathrm{rpm}$ for $10 \mathrm{~min}$ ) and washed three times. The washed resin was then resuspended in $150 \mu \mathrm{I}$ of $2 \times$ electrophoresis sample buffer (125 mM Tris-HCl, $4 \%$ SDS, $20 \%$ glycerol, $10 \% \beta$-mercaptoethanol) and boiled for $3 \mathrm{~min}$. After centrifugation in an Eppendorf microfuge, the supernatant was subjected to SDS gel electrophoresis. The electrophoretically separated proteins were then analyzed either by Western blotting using the antibodies specific for glutamate receptor subunits or by silver staining (Giulian et al., 1983).

Deglycosylation. Membranes from rat cerebellum or transfected cells were pelleted and resuspended in phosphate buffered saline (PBS), $\mathrm{pH}$ 7.2 , containing $1 \%$ SDS. The resuspended membranes were then boiled for $2 \mathrm{~min}$. Octylglucoside $(1 \%)$ and the protease inhibitors phenylmethylsulfonyl fluoride (PMSF; $0.5 \mathrm{~mm})$, leupeptin $(10 \mu \mathrm{g} / \mathrm{ml})$ and pepstatin $(10 \mu \mathrm{g} / \mathrm{ml})$ werc then added to their final concentrations indicated above, and the SDS concentration was reduced to $0.1 \%$. Recombinant $\mathrm{N}$-glycosidase F (Boehringer Mannheim, Indianapolis, IN) was added to a final concentration of $0.8 \mathrm{U} / 100 \mu \mathrm{l}$ and incubated overnight at $37^{\circ} \mathrm{C}$. Controls were treated in the same way except that no enzyme was added. Samples were resuspended in electrophoresis sample buffer and analyzed by SDS-PAGE.

Protease digestion. Homogenates of cerebellum and 81 - and 82 -transfected HEK-293 cells were centrifuged in an Eppendorf microfuge for $2 \mathrm{~min}$. The pellets were then resuspended in $0.125 \mathrm{M}$ Tris/ $\mathrm{HCl}(\mathrm{pH} 6.8$ ) containing $0.5 \%$ SDS and boiled for $2 \mathrm{~min}$. For each preparation, V8 protease (Endoproteinase Glu-C, Boehringer Mannheim) at three different concentrations $(0.01 \mathrm{mg} / \mathrm{ml}, 0.1 \mathrm{mg} / \mathrm{ml}$, and $1 \mathrm{mg} / \mathrm{ml})$ was then added to the samples, and each was incubated for $30 \mathrm{~min}$ at $37^{\circ} \mathrm{C}$. Control samples without protease were also included in the experiment. After 1 vol of $2 \times$ electrophoresis sample buffer was added, each sample was boiled for $3 \mathrm{~min}$ prior to SDS-PAGE and Western blot analyses using the anti- $\delta 1 / 2$ antibody.

Ligand binding. Rat cerebellar membranes were solubilized with $1 \%$ Triton X-100 for ligand binding studies as described (Wenthold et al., 1992 , 1994). Binding analyses were done using $10 \mathrm{~nm}{ }^{3} \mathrm{H}$-AMPA, 10 nM ${ }^{3} \mathrm{H}$-glutamate, and $5 \mathrm{~nm}{ }^{3} \mathrm{H}$-kainate. Incubations with radioactive ligand were carried out for $30 \mathrm{~min}$ followed by precipitation with polyethylene glycol. To determine immunoprecipitation of ligand binding activity, $100 \mu \mathrm{l}$ of antiserum was incubated with $100 \mu \mathrm{l}$ of protein AAgarose (Pierce Chemical Co., Rockford, IL) for $1.5 \mathrm{hr}$, and the resin with the bound antibody was washed extensively. Detergent solubilized cerebellum $(500 \mu \mathrm{l})$ was incubated with the resin for $1.5 \mathrm{hr}$ at $4^{\circ} \mathrm{C}$. Binding activitics in the unbound fractions were detcrmined and compared to values obtained using pre-immune serum or normal serum.

Immunocytochemistry. Young male Sprague-Dawley rats (119-184 gm) were anesthetized with a 1:1 mixture of ketamine (Ketaset, Aveco Co., Fort Dodge, IA) and xylazine (Rompun, Mobay Corp., Shawnee, KS), and perfused transcardially, as described previously (Petralia and Wenthold, 1992; Petralia et al., 1994a), with $0.12 \mathrm{M}$ phosphate buffer (pH 7.2) followed by 4\% paraformaldehyde (in same buffer) with or without $0.1 \%$ glutaraldehyde for light/electron or light microscopy, respectively.

The most useful anti- $\delta 1 / 2$ antibody concentrations were $0.5-1.5 \mu \mathrm{g} /$ $\mathrm{ml}$. We used a preembedding immunocytochemical procedure as described in detail previously (Petralia and Wenthold, 1992; Petralia et al., 1994a). Briefly, $50 \mu \mathrm{m}$ sections were blocked in $10 \%$ normal goat serum/PBS, incubated overnight in primary antibody and visualized using an avidin-biotin-peroxidase system (Vectastain kit, Vector Laboratories, Burlington, $\mathrm{CA}$ ) and 3',3-diaminobenzidine tetrahydrochloride (DAB; $10 \mathrm{mg} / 20 \mathrm{ml} \mathrm{PBS}+5 \mu \mathrm{l} 30 \%$ hydrogen peroxide). Sections for electron microscopy were fixed in $1 \%$ osmium tetroxide and embedded in Poly/BED 812 resin (Polysciences, Inc., Warrington, PA). Yellow sections (average $75 \mathrm{~nm}$ ) were taken from the edge (i.e., perpendicular to the plane of the section) of the $50 \mu \mathrm{m}$ sections on an LKB Ultratome IV ultramicrotome, and examined unstained in a JEOL JEM-100CX II transmission electron microscope.

Controls. Sections in which PBS was substituted for the primary antibody (PBS controls) were run in cvery experiment, for all structures studied. In addition, preadsorption control tests (two rats) were run on sections of all structures studied; sections were incubated with antibody which was preincubated with specific peptide conjugated to BSA (50 $\mu \mathrm{g} / \mathrm{ml}$ ), along with appropriate accompanying sections treated with primary antibody (without peptide) and sections with primary antibody and glutaraldehyde-treated BSA $(50 \mu \mathrm{g} / \mathrm{ml}$; without peptide). In addition, in most experiments, some sections were run with one or more other polyclonal, C-terminus glutamate receptor antibodies (GluR1, GluR2/3, NR1) as positive controls; these were made similarly to the $\delta$ antibody and have been fully characterized and used for light and electron microscope distribution studies (Petralia and Wenthold, 1992; Wenthold et al., 1992; Petralia et al., 1994a).

Anatomical survey. Basic procedures were as described in previous studies (Petralia and Wenthold, 1992; Petralia et al., 1994a-c; Tachibana et al., 1994). Sagittal sections (seven sides of six rats) were taken from up to six levels (PW79-85; i.e., corresponding to Figs. 79-85 in Paxinos and Watson, 1986). Coronal sections (two rats) included some sections from PW28-33, PW42-43, and PW54-64. Transverse sections from cervical spinal cord (four rats), cervical dorsal root ganglia (four rats), pituitary glands (four rats), and pineal glands (three rats) were examined. Thin sections for electron microscopy (two rats) of cerebellar cortex were taken from sagittal vibratome sections

As described previously (Petralia and Wenthold, 1992; Petralia et al., 1994a), choice of optimum antibody concentrations was based on the presence of dense staining in some structures as compared to PBS control sections. Typically, staining penetrated several micrometers on both sides of the section; lack of staining in the middle of the width of the section was considered in all assessments of light and electron microscope localization of staining. Staining is described as "neuropilar" and "neuronal," as defined in Petralia and Wenthold (1992; also Petralia et al., 1994a), i.e., neuronal staining refers to staining of the cell body, excluding nucleus, and the major dendrites which could be traced from the cell body, while neuropilar staining includes processes not traced to specific cell bodies and the unresolvable matrix between cells. In white 

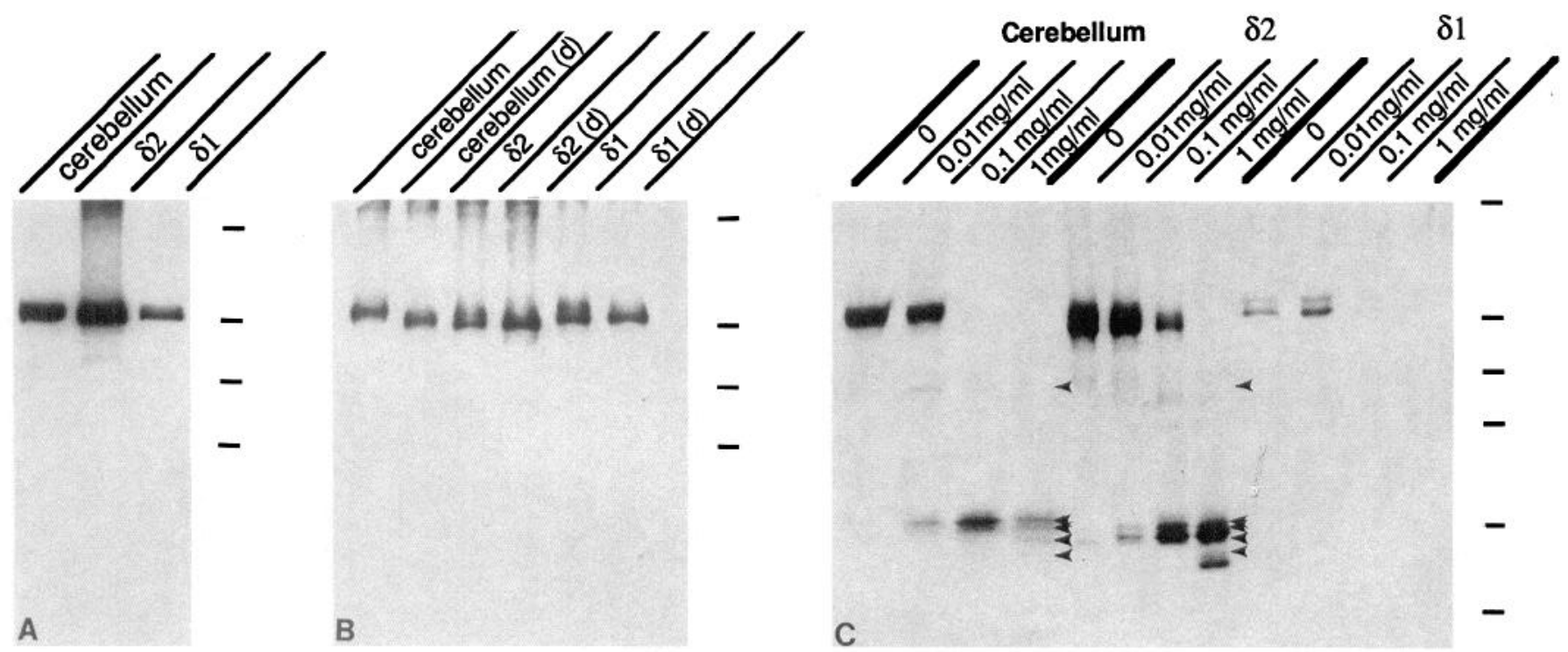

Figure 1. SDS-PAGE and immunoblot analysis of rat cerebellum and transfected cell membranes using an antibody directed against a peptide corresponding to the C-terminus of the $\delta 2$ subunit. An intense immunoreactive band is seen in cerebellum, as well as membranes from HEK-293 cells transfected with $\delta 2$, and membranes from cells transfected with $\delta 1$ cDNAs $(A)$. The broad immunoreactive bands present in transfected cell membranes can be resolved into two bands $(B)$ when less intensely developed. Deglycosylation $(d)$ with $N$-glycosidase F eliminated the higher molecular weight band of both $\delta 1$ and $\delta 2$ transfected cell membranes and reduced the size of the immunoreactive band in cerebellum $(B)$. $C$, Comparison of peptide maps of $\delta 1 / 2$-immunoreactive proteins in the cerebellum and transfected cell membranes using increasing concentrations of V8 protease. Similarly migrating immunoreactive bands were found in the cerebellum and $\delta 2$-samples (arrowheads). Bars show the position of the prestained standards, myosin $\left(M_{r}=203,000\right)$, phosphorylase b $\left(M_{r}=105,000\right)$, BSA $\left(M_{r}=70,800\right)$, and ovalbumin $\left(M_{r}=43,600\right)$. Additional lower molecular weight standards, carbonic anhydrase $\left(M_{r}=28,250\right)$ and $\beta$-lactoglobulin $\left(M_{r}=17,900\right)$, are shown in $(C)$. Molecular mass estimates were obtained in a separate experiment and are based on unstained standards run in parallel with the sample.

matter, very small, stained cells, typically elongate-multipolar, were presumed to be glia, probably astrocytes, as noted in previous articles (Petralia and Wenthold, 1992; also Petralia et al., 1994a-c; Tachibana et al., 1994). Our descriptions of immunostaining in large structures of the brain (e.g., hypothalamus, septum, thalamus, etc.) can be considered valid for the portion examined only, since such structures extend beyond the sections examined as described above, and as noted previously ( $\mathrm{Pe}-$ tralia and Wenthold, 1992). Identification of structures with electron microscopy was based on defined criteria (e.g., Peters et al., 1991), as reviewed previously (Petralia and Wenthold, 1992; Petralia et al., 1994a).

\section{Results}

Properties of antibodies to $\delta$ subunits

The carboxyl terminus of $\delta 2$ was chosen as the target of antibody production based on previous studies on other glutamate receptor subunits which showed that the carboxyl terminus peptides were useful for producing antibodies that could be applied to immunoprecipitation, Western blotting and immunocytochemistry (Wenthold et al., 1990, 1992; Petralia and Wenthold, 1992; Petralia et al., 1994a-c). The $\delta 2$ peptide used (QPTPTLGLNLGNDPDRGTSI) contains several amino acids also present in the corresponding region of $\delta 1$ (underlined amino acids). Western blot analysis of membranes from cells transfected with $\delta 1$ and $\delta 2$ cDNAs showed that the antibody recognizes both $\delta 1$ and $\delta 2$ (Fig. 1A). Based on these results, we conclude that immunoreactivity detected in brain is due to both $\delta 1$ and $\delta 2$ subunits, and refer to the antibody as anti- $\delta 1 / 2$ antibody. Both $\delta 1$ and $\delta 2$ samples showed a broad immunoreactive band that can be resolved into two bands when less sample is applied or when the gels are developed lighter (Fig. 1B). The lower molecular weight components appear to represent deglycosylated forms of the proteins since treatment with the $\mathrm{N}$-glycosidase F converted the higher molecular weight form into the lower molecular weight form (Fig. 1B). The estimated molecular mass for the $\delta 2$ protein expressed in HEK-293 cells was determined to be $110 \pm 3 \mathrm{kDa}$ $(n=5)$ for the glycosylated form and $104 \pm 2 \mathrm{kDa}(n=4)$ for the deglycosylated form. For $\delta 1$ expressed in HEK-293 cells, the molecular mass was estimated to be $115 \pm 2 \mathrm{kDa}(n=5)$ for the glycosylated form and $109 \pm 3 \mathrm{kDa}$ for the deglycosylated form. Immunoblot analysis of the cerebellum, where $\delta 2$ expression is reported to be heaviest (Araki et al., 1993; Lomeli et al., 1993), showed a single major band with a molecular mass estimated to be $114 \pm 2 \mathrm{kDa}(n=4)$; after treatment with $N$ glycosidase $\mathrm{F}$, the mass was reduced to $110 \pm 3 \mathrm{kDa}(n=4)$. The similarity in sizes between $\delta 1$ and $\delta 2$ expressed in HEK293 cells, and the fact that the major immunoreactive band in cerebellum did not exactly comigrate with $\delta 2$ from transfected cells, raised the possibility that the antibody was not recognizing $\delta 2$ in cerebellum, but rather $\delta 1$ or a related protein. To verify that the major protein recognized in the cerebellum by the anti$\delta 1 / 2$ antibody is $\delta 2$, peptide maps of cerebellum and membranes from cells transfected with $\delta 1$ and $\delta 2$ cDNAs were generated by limited digestion with V8 protease. The immunoreactive peptide pattern generated from cerebellum closely resembled that generated from $\delta 2$, while that from $\delta 1$ was devoid of immunoreactive peptides suggesting that immunoreactive peptides too small to be resolved on the gel are produced (Fig. $1 C$ ). The slight difference in migration rates between cerebellar $\delta 2$ and $\delta 2$ from transfected cells could be due to modifications other than $\mathrm{N}$-glycosylation which differentially affect the protein from the two sources. While our value of 109,000 Da for the molecular mass of the deglycosylated $\delta 1$ subunit fits that of the calculated molecular mass of $110,440 \mathrm{Da}$, our value of $104,000 \mathrm{Da}$ for the deglycosylated $\delta 2$ subunit from transfected cells is somewhat lower than the calculated value of 113,229 Da (Hollmann and 


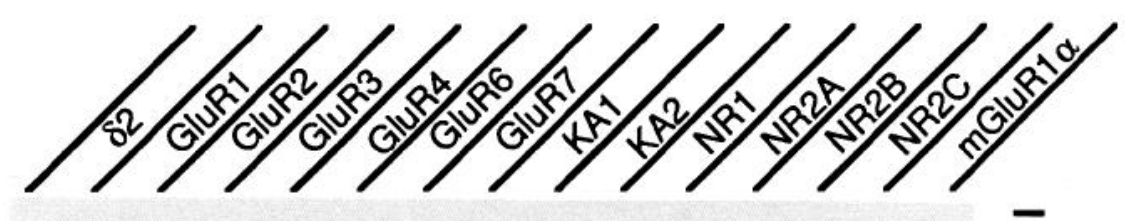

Figure 2. Specificity of anti- $\delta 1 / 2$ antibodies in relation to other glutamate receptor subunits. Glutamate receptor subunits were expressed in HEK-293 cells and examined by SDS-PAGE and immunoblot analysis with anti- $\delta 1 / 2$ antibodies. Staining was done using the chemiluminescence detection system. Standards are as described for Figure $1, A$ and $B$. To assure that sufficient receptor protein was applied to the gels to detect possible antibody cross-reaction, expression was determined using the respective subunit-specific antibody in all cases except KA1, for which a specific antibody has not been reported.

Heinemann, 1994). The value we obtain for the deglycosylated $\delta 2$ subunit in the cerebellum, 110,000 , is similar to the calculated value of the $\delta 2$ subunit.

To characterize the specificity of the anti- $\delta 1 / 2$ antibodies with respect to other members of the glutamate receptor family, the
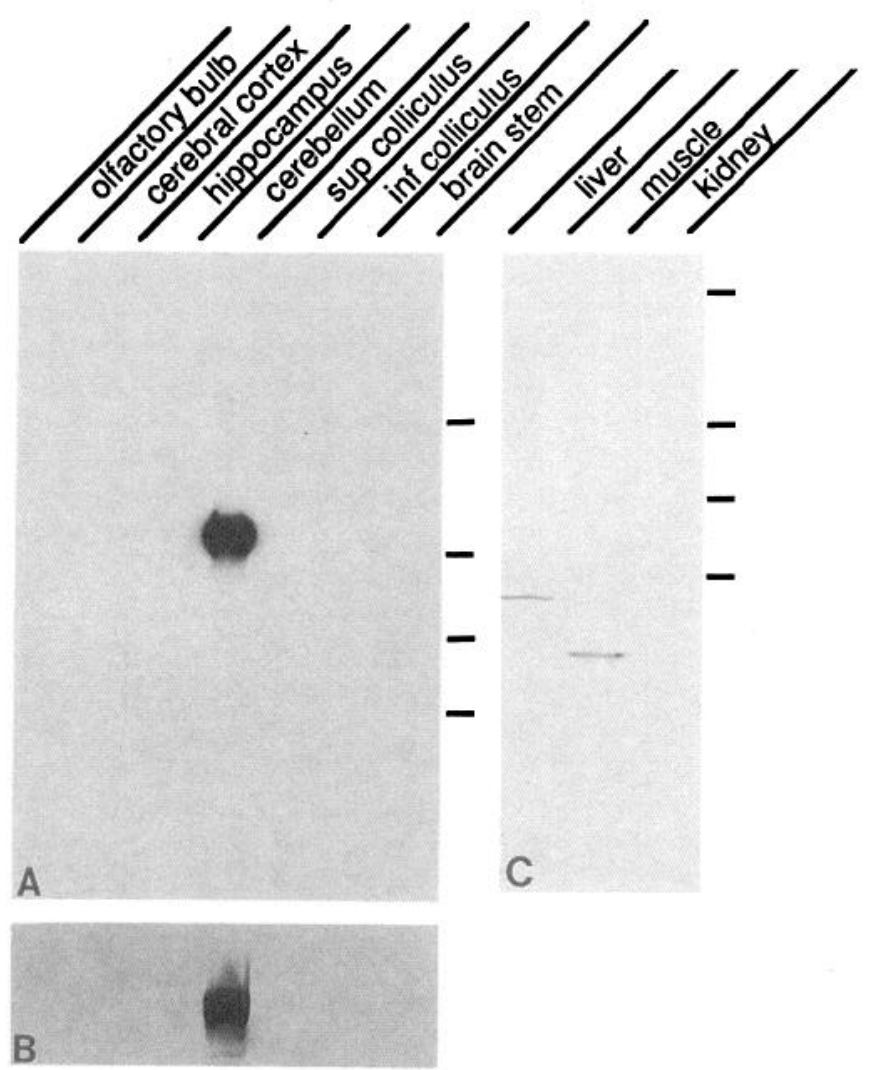

Figure 3. Distribution of $\delta 1 / 2$ immunoreactivity in the rat CNS and peripheral tissues. The cerebellum shows a major immunoreactive band with no staining in other CNS samples $(A)$, but with prolonged staining a low level of immunoreactivity was seen in other brain regions $(B)$. No staining was detected in the non-neuronal samples of liver, muscle, and kidney $(C)$. Staining was done with the chemiluminescence $(A)$ or alkaline phosphatase $(B, C)$ detection systems. Standards are as described for Figure $1, A$ and $B$. antibody was tested on immunoblots of membranes from HEK293 cells transfected with the cDNAs of different glutamate receptor subunits including GluR1, GluR2, GluR3, GluR4, GluR6, GluR7, KA1, KA2, NR1, NR2A, NR2B, NR2C, and mGluR1 $\alpha$ (Fig. 2). The antibody did not recognize any of the other subunits.

Using the Western blotting technique, regional distribution analysis of $\delta 1 / 2$ immunoreactivity in the adult rat nervous system demonstrated its marked presence in cerebellum compared to other areas of the brain (Fig. 3). Only with intense development are light immunoreactive bands seen in samples of other brain regions (Fig. $3 B$ ). Since the antibody recognizes both $\delta 1$ and $\delta 2$, the staining likely represents both of the subunits. Immunolabeling of $\delta 1$ or $\delta 2$ is not seen in non-neuronal tissues (Fig. $3 C$ ). In all brain samples, no additional immunoreactive bands are detected indicating that there is no significant crossreaction with other proteins. In control experiments in which the antibody was preincubated with the peptide $(0.2 \mathrm{mg} / \mathrm{ml})$ used for immunization, immunoreactivity was eliminated in immunoblots of cerebellar homogenates and of $\delta 1-$ and $\delta 2$-transfected HEK-293 cells (data not shown).

\section{Immunoprecipitation}

Since it showed the highest expression of $\delta$ protein (Fig. 3), the cerebellum was used to investigate the relationship of the $\delta$ subunits with other glutamate receptor subunits. Triton X-100 solubilized cerebellar membranes were immunoprecipitated with anti- $\delta 1 / 2$ antibodies and analyzed by Western blotting using antibodies to AMPA (GluR2/3), kainate (GluR6/7, KA2), NMDA (NR1, NR2A/B), and metabotropic (mGluR1 $\alpha$ ) receptor subunits, as well as with antibodies to $\delta 1 / 2$. Only the $\delta$ subunits were immunoprecipitated (Fig. 4), suggesting that subunits of AMPA, kainate, NMDA and mGluR $1 \alpha$ receptors do not form molecular complexes with the $\delta$ subunits. To investigate the possibility of other coimmunoprecipitating proteins, the immunoprecipitated product was silver stained. A major band comigrating with the immunostained $\delta$ subunits was seen along with several minor unidentified bands (Fig. 4). It therefore appears that the major immunoprecipitated bands represent the $\delta$ subunits, or the $\delta$ subunits and other comigrating proteins. 


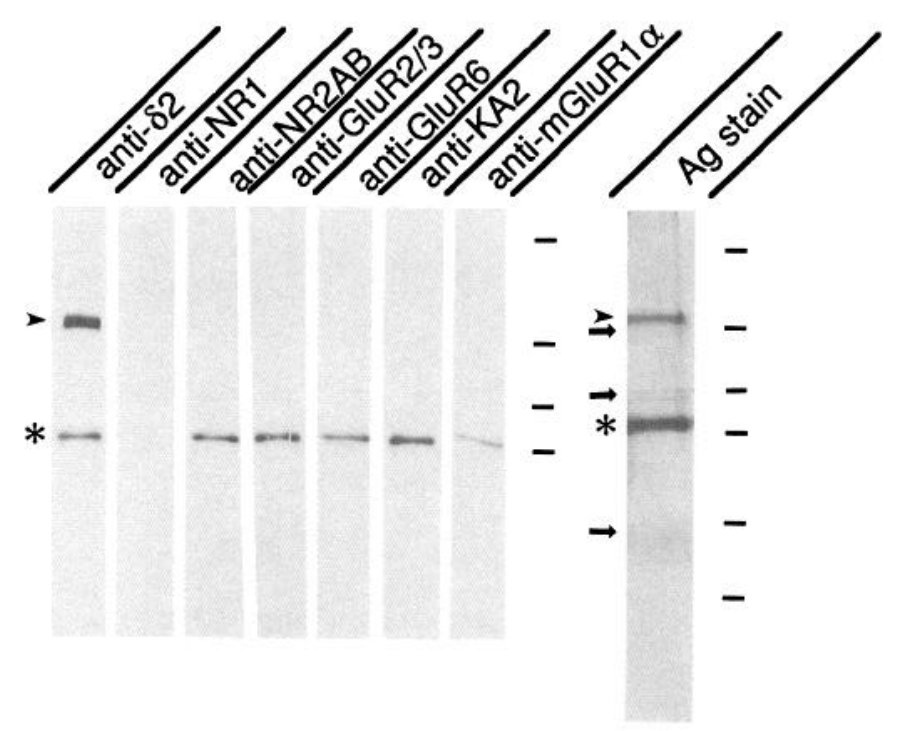

Figure 4. Immunoprecipitation of Triton X-100 solubilized rat cerebellar membranes with anti- $\delta 1 / 2$ antibodies. Immunoprecipitated proteins were electrophoretically separated and analyzed either by immunoblotting with antibodies directed against the glutamate receptor subunits, $\delta 1 / 2$, NR1, NR2A/B, GluR2/3, GluR6/7, KA2, and mGluR1 $\alpha$ (left) or by silver staining. Except for the anti-NR1 antibody which is a monoclonal antibody raised in mice, all the other antibodies used were made in rabbits. The bands noted by the asterisk correspond to the IgG heavy chain which is prominent when antibodies made in rabbits are used for immunoblotting. A band corresponding to the $\delta 1 / 2$ subunits was immunoprecipitated (arrowhead), while none of the other glutamate receptor subunits were detected. Silver staining identified a major band which comigrates with the immunostained $\delta$ subunits (arrowhead). Additional unidentified minor bands (arrows), as well as IgG heavy chain (asterisk) were also detected by the silver staining method. Standards are as described in Figure 1.

\section{Ligand binding}

Since the above studies showed that the antibodies were effective in immunoprecipitating $\delta$ subunits from Triton X-100 solubilized cerebellar membranes, we used immunoprecipitation to determine if excitatory amino acid ligand binding activity was associated with the $\delta$ subunits. Triton X-100 has been shown to solubilize AMPA and kainate receptors that retain their ligand binding properties (Hampson et al., 1987; Hunter et al., 1990), and previous studies have demonstrated immunoprecipitation of ligand binding activity with antibodies to the carboxyl terminus of AMPA and kainate receptors (Wenthold et al., 1992, 1994). Using this approach, anti- $\delta 1 / 2$ antibodies did not immunoprecipitate ${ }^{3} \mathrm{H}$-AMPA, ${ }^{3} \mathrm{H}$-glutamate, or ${ }^{3} \mathrm{H}$ kainate binding activity from Triton X-100 solubilized cerebellar membranes (Table 1).

\section{Developmental profile of $\delta$-subunits in the cerebellum}

Although the above studies indicate that the $\delta$ subunits do not form a molecular complex with AMPA, kainate, NMDA, and mGluR $1 \alpha$ receptors, it is possible that $\delta$ receptors are functionally associated with other glutamate receptor populations. Such a relationship may be indicated by similar developmental patterns (e.g., Ryo et al., 1993). To address this we studied the developmental expression of the $\delta$ subunits in relation to that of representative subunits of AMPA (GluR2/3), kainate (GluR6/7), NMDA (NR1), and metabotropic (mGluR1 $\alpha$ ) receptors in the cerebellum. These results (Fig. 5) show a dramatic increase in $\delta 1 / 2$ immunoreactivity between 10 and $15 \mathrm{~d}$
Table 1. Immunoprecipitation of detergent-solubilized AMPA, glutamate, and kainate binding sites from rat cerebellum using anti- $\delta 1 / 2$ antibodies

${ }^{3} \mathrm{H}$-AMPA $\quad{ }^{3} \mathrm{H}$-Glutamate $\mathrm{H}-\mathrm{KA}$

Percentage of binding recovered

$101.9 \pm 4.6 \quad 105.0 \pm 6.0 \quad 107.8 \pm 4.6$

Data represent the percentage of binding unretained by a column of protein A-agarose to which $100 \mu \mathrm{l}$ of antiserum was attached, compared to that obtained with preimmune serum. Values are the means \pm SEM for four or five determinations done in duplicate.

of age, different from developmental patterns of other receptor subunits studied, except for that of mGluR $1 \alpha$ which also shows a significant, although less dramatic, increase at this same time (see also Shigemoto et al., 1992; Ryo et al., 1993).

Light microscope distribution of $\delta 1 / 2$ immunoreactivity in the adult

Except for the cerebellum, neurons and neuropil of most regions of the brain stained lightly to moderately, while glia stained lightly throughout the white matter of the brain (Figs. $6,7)$. In the main olfactory bulb, moderate staining was found in neuropil of the glomerular and external plexiform layers, while the granule cell layer stained lightly and mitral cells stained moderately to moderately dense (Fig. 7a). Staining of the external plexiform layer of the accessory olfactory bulb (Fig. 6) often was moderately dense; otherwise staining in the accessory olfactory bulb was similar to that of the main olfactory bulb. Neuropil and neurons of the cerebral cortex typically
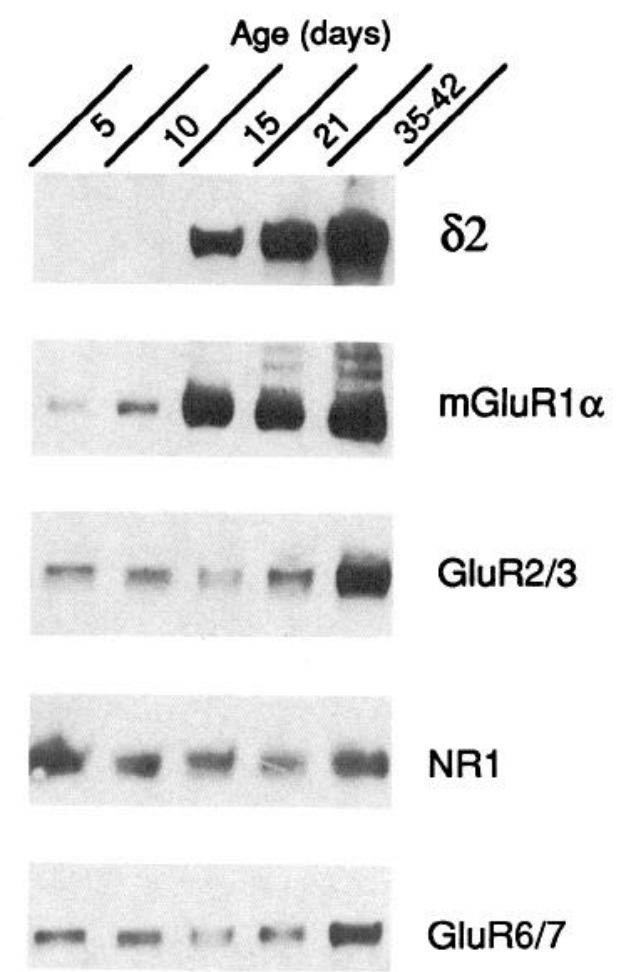

Figure 5. Patterns of developmental expression of the glutamate receptor subunits $\delta 1 / 2$, mGluR $1 \alpha$, GluR2/3, NR1, and GluR $6 / 7$ in the rat cerebellum. Eighteen micrograms of protein was applied to each lane. At all ages, samples analyzed with the different antibodies were obtained from the same preparation of cerebellum. 

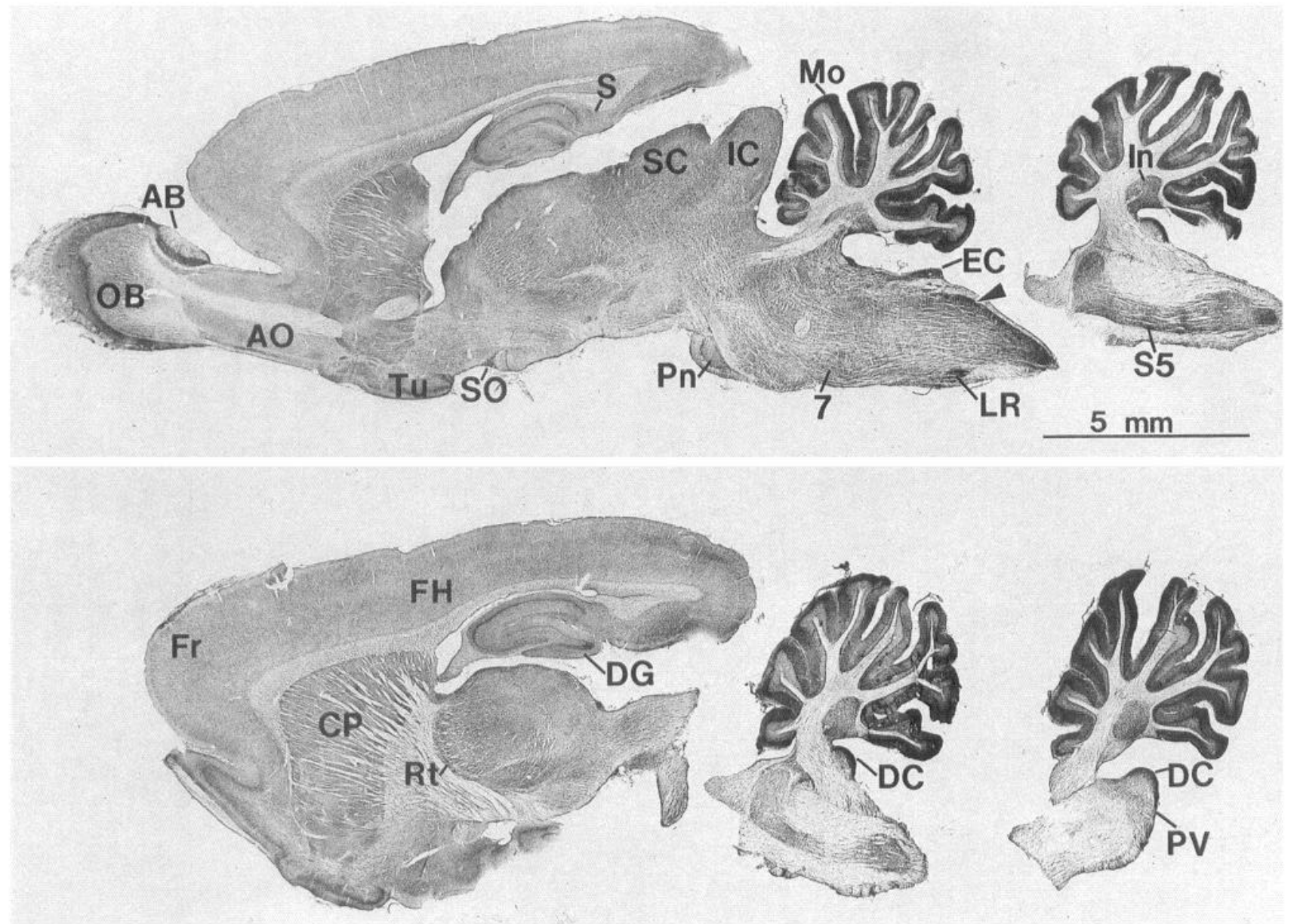

Figure 6. Low magnifications of sagittal sections immunolabeled with antibody to $\delta 1 / 2$. Full sections correspond most closely to Figures 81 (top) and 83 (bottom) of Paxinos and Watson (1986; PW81,83); additional hindbrain sections correspond most closely to PW83 (top) and PW85 (bottom). $A O$, Anterior olfactory $\mathrm{n}$.; $A B$, accessory olfactory bulb; $C P$, caudate-putamen; $D C$, dorsal cochlear n.; $D G$, dentate gyrus; $E C$, external cuneate $\mathrm{n}$.; $F H$, forelimb/hindlimb area of cortex; $F r$, frontal cortex; $I C$, inferior colliculus; $I n$, interposed cerebellar n.; $L R$, lateral reticular n.; $M o$, molecular layer of cerebellar cortex; $O B$, olfactory bulb; $P n$, pontine n.; $P V$, posteroventral cochlear n.; Rt, reticulothalamic n.; $S$, subiculum; $S C$, superior colliculus; $S O$, supraoptic n.; $S 5$, spinal trigeminal n.; Tu, olfactory tubercle; 7 , facial n.; arrowhead, marginal zone of caudal part of spinal trigeminal $\mathrm{n}$. Magnification, $5.5 \times$.

stained lightly, although layer V pyramidal cells (Fig. $7 b$ ), some neurons of the deep layer VI, and some neurons scattered through other layers, stained moderately. In the hippocampus, neuropilar staining was moderate in the stratum oriens (CA1CA3), molecular layer of the dentate gyrus, and outermost layer of the CA1 molecular layer (i.e., stratum lacunosum-moleculare), and light in the molecular layer of CA1-CA3 and in the hilus (Fig. $7 c, d$ ). The CA1-CA3 pyramidal cell layer contained moderate staining. Light to moderate staining was found in small/medium neurons throughout the stratum oriens and molecular layer of CA1-CA3 and in the hilus. Hilar neurons found on the edge of the granule cell layer often were stained moderately; these cells resembled those described as dentate pyramidal basket cells and type two dentate basket cells (Amaral, 1978; also Ribak and Seress, 1983), although identification was not definitive since usually only the cell bodies and bases of the major dendrites were distinct (Fig. $7 d$ ). Often these cells were distinguished easily from the adjacent granule cell bodies which typically stained lightly or were unstained. Neuropil of the caudate-putamen was stained lightly to moderately. Most neurons stained lightly or were unstained, al- though moderate staining was found in a few medium/large neurons (Fig. 7e). Staining typically was light in most neurons and neuropil of the dorsal parts of the thalamus (e.g., lateral dorsal and lateral posterior nuclei), while it was moderate in ventral parts (e.g., ventrolateral and ventromedial nuclei), as well as in the reticulothalamic (Fig. 6) and anterodorsal nuclei. In the hypothalamus, staining typically was light to moderate in neurons and neuropil, while staining in scattered neurons and those of the supraoptic nucleus (Fig. 6) was moderate to moderately dense.

In the midbrain, the periaqueductal gray contained lightly to moderately stained neurons in a moderately stained neuropil; staining of neurons in the adjacent oculomotor nuclei was similar although the neuropil stained moderately to moderately dense. In the superior colliculus (Fig. 6), neuropil stained lightly to moderately; most neurons stained lightly, although large, multipolar neurons of deep layers stained moderately. In contrast, moderately stained neurons were seen commonly throughout the inferior colliculus (Fig. 6) which contained moderately stained neuropil.

In the hindbrain, moderately dense neuronal and neuropilar 

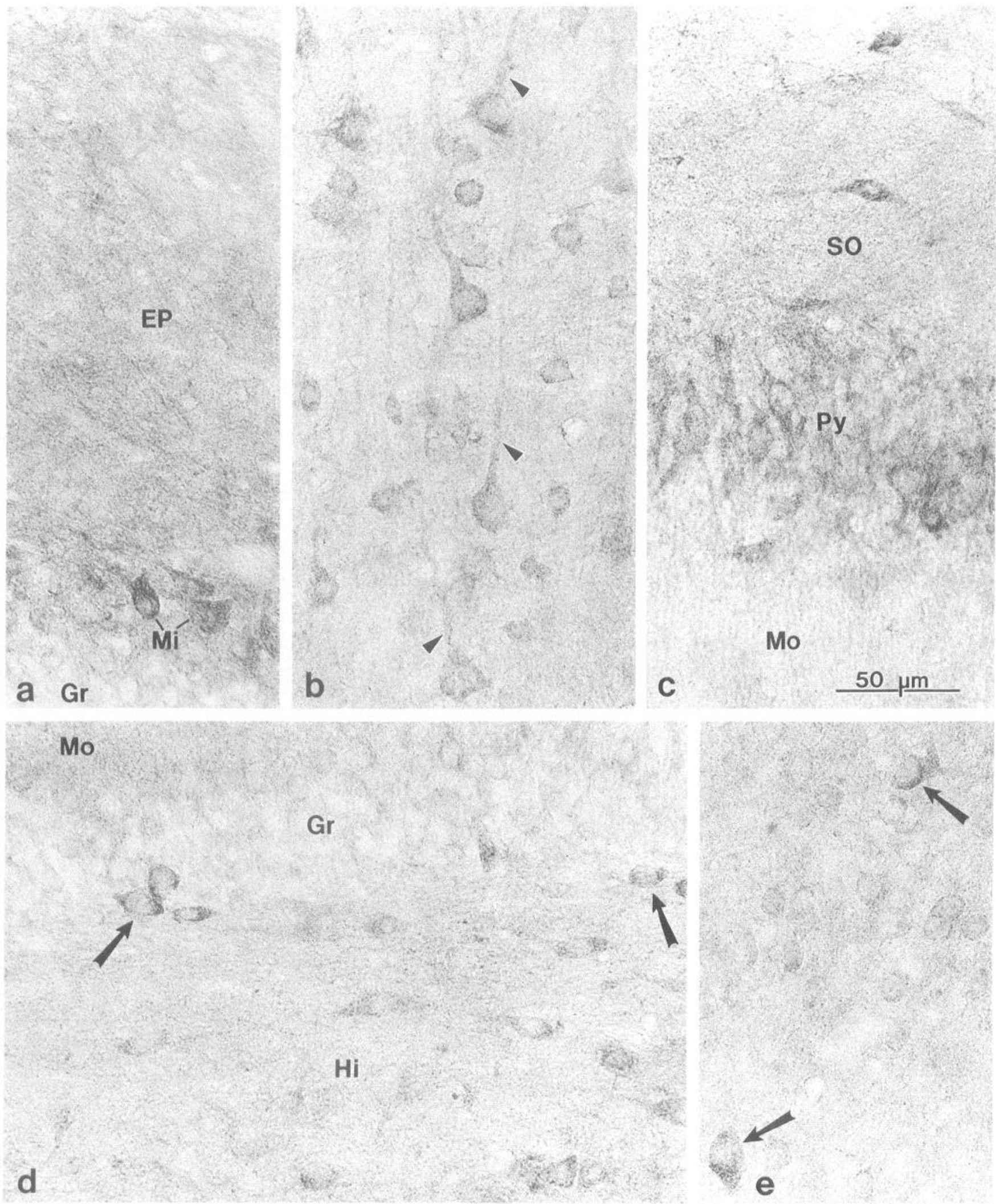

Figure 7. Sagittal sections of forebrain structures immunolabeled with antibody to $\delta 1 / 2$. $a$, Olfactory bulb. $E P$, External plexiform layer; $G r$, granule cell layer; $M i$, mitral cell. $b$, Layer 5 of forelimb/hindlimb cortex. arrowheads, Apical dendrites of pyramidal cells. $c$, CA2 region of hippocampus. SO, Stratum oriens; Py, pyramidal cell layer; $\mathrm{Mo}$, molecular layer. $d$, Dentate gyrus. $\mathrm{Gr}$, Granule cells; $\mathrm{Hi}$, hilus; $\mathrm{Mo}$, molecular layer; arrows, hilar neurons on border of granule cell layer. $e$, Caudate/putamen. Moderate staining is present in only a few cells (arrows). Magnification, $438 \times$. 

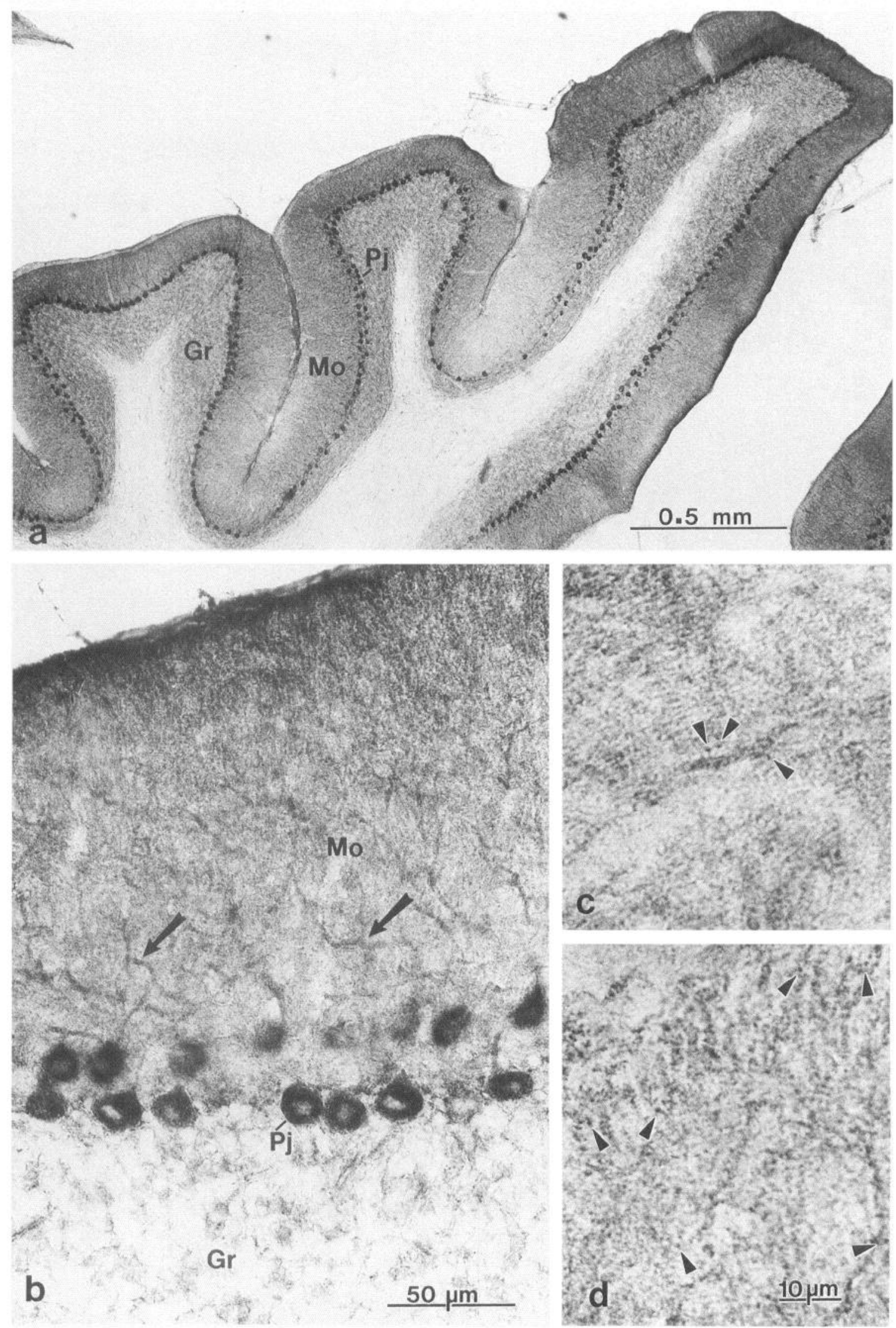

Figure 8. Sagittal sections of cerebellum immunolabeled with antibody to $\delta 1 / 2$. Gr, Granular layer; $M o$, molecular layer; $P j$, Purkinje cells; arrows, Purkinje cell dendrites. $c$ and $d$, High magnifications of middle $(c)$ and upper $(d)$ regions of molecular layer. Note densely stained puncta (arrowheads) associated with moderately stained dendrites, and sometimes appearing to be situated apically on putative dendritic spines (especially 
staining was found in the outer layers of the dorsal cochlear nucleus, while neurons/neuropil of the lateral reticular nucleus, and neuropil of the marginal zone of the caudal part of the spinal trigeminal nuclcus, stained modcratcly to moderately dense (Fig. 6). However, neuronal staining of the marginal zone often was obscured by the neuropilar staining. In addition, neuropil and neurons of many hindbrain structures stained moderately, most notable being that of the trigeminal and facial motor nuclei (Fig. $6)$.

Densest staining in the nervous system overall was found in the cerebellum, most notably in Purkinje cell bodies which stained densely (Figs. 6, 8). The molecular layer contained moderately dense stained neuropil and a few, lightly stained small cells. Staining of the granular layer was moderate, but staining in granule cells was difficult to delineate due to the scantness of the cytoplasm. Staining in the granular layer was seen most prominently as a network of fine processes outlining granule cells and as scattered patches of staining in the neuropil. Densely stained puncta were common in the molecular layer, especially in the outer third, but were uncommon in the granular layer. At high magnifications, puncta of the molecular layer often appeared to represent dendrite spine heads (Fig. $8 c, d$ ), matching, in size and shape, the immunolabeled structures identified with electron microscopy (Fig. $9 a, c$; see below). Bergmann glial processes usually were not stained, but sometimes stained lightly.

Substantial staining was seen in some structures outside of the brain (data not shown). In the spinal cord dorsal horn, neurons and neuropil stained moderately to moderately dense, but neuronal staining sometimes was obscured by the neuropilar staining. Motoneurons of the spinal cord stained moderately in a lightly to moderately stained neuropil. Moderate staining was found in ganglion cells of the dorsal root, while light to moderate staining was found in ganglion cells of the vestibular ganglia. Staining of the pineal gland was dense with densely stained puncta. Staining of the pituitary gland was moderate to moderately dense in the anterior lobe, light in the intermediate lobe, and moderately dense in the posterior lobe, which contained numerous stained processes and puncta.

\section{Electron microscope distribution of $81 / 2$ immunoreactivity in the adult cerebellum}

Staining was often dense in cytoplasm of Purkinje cells, while granule cell body cytoplasm contained little or no staining. The most prominent staining was in postsynaptic densities in spines of parallel fiber synapses of the molecular layer (Fig. 9). Most of these synapses could be identified as parallel fiber/Purkinje spine synapses, based on defined criteria (Mugnaini, 1972; Palay and Chan-Palay, 1974). Typical characteristics included (1) a stained postsynaptic density on the side of an oval spine head attached to a narrow neck (both usually stained); (2) an unstained synaptic cleft; (3) an unstained presynaptic terminal filled with round vesicles, among parallel fibers (bundles of unmyelinated axons in compact, parallel formation; often the synapse was continuous with a parallel fiber in the section); (4) contact between the presynaptic terminal and the postsynaptic spine limited mainly to the active zone; and (5) wrapping of synapse with glial processes; these glial processes sometimes were stained. These stained synapses were most common in the outer portion of the molecular layer where often several of them could be seen to branch from the same, stained dendritic shaft. Typically, the dendritic shaft bore characteristics of a Purkinje cell shaft including numerous mitochondria and large size $(1 \mu \mathrm{m}$ or more in caliber). Staining of postsynaptic densities and dendrites corresponded to staining of puncta and dendrites seen with light microscopy (Fig. $8 c, d$; see above). Stained postsynaptic densities also were found in some other forms of synapses, including those with neckless spines or synapses directly on the dendritic shaft. Stained synapses were rare in the granular layer. Only one definitive example was seen; this was a dendrite process with stained cytoplasm and postsynaptic density apposed to an unstained terminal in a glomerulus.

In addition to staining in postsynaptic densities and cytoplasm in the molecular layer, staining also was common in glial processes in all layers, and including both thin, irregular processes with attenuated cytoplasm and larger processes containing bundles of filaments. These glial processes included many astroglial sheaths which surround glomeruli and granular cells, some glial wrappings of parallel fiber/Purkinje spine synapses in the molecular layer, and some glial processes surrounding blood vessels, myelinated and unmyelinated axons, and dendrites. Staining for $\delta$ in glia is not surprising considering that there is substantial evidence that various types of glia contain AMPA, kainate, metabotropic, and probably NMDA receptors (e.g., Petralia and Wenthold, 1992; Tanabe et al., 1993; Uchihori and Puro, 1993; Gallo et al., 1994; Petralia et al., 1994a,c).

Staining was uncommon in other structures, although many small, unidentified processes were stained. Only occasional staining was found in putative parallel fibers. Presynaptic staining was rare and never definitive.

\section{Controls for immunocytochemistry}

Sections of brain, ganglia, and endocrine glands in which PBS was substituted for the primary antibody (PBS controls) were unstained except for occasional light staining in glia of the hindbrain. In sections of spinal cord, gray matter, and inner portions of white matter were unstained, but substantial staining often was present in glia of the outer portions of the white matter. A few, lightly stained, unidentifiable processes were found in the posterior pituitary lobe. Results of preadsorption control experiments were similar to those of PBS controls for all structures.

\section{Discussion}

In this study, we developed an antibody selective for the glutamate receptor $\delta$ subunits and used it to characterize the biochemical and immunocytochemical properties of the $\delta$ proteins in the rat CNS. The antibody was made to a 20 amino acid peptide corresponding to the C-terminus of $\delta 2$, and recognizes both $\delta 1$ and $\delta 2$. The antibody does not recognize several other glutamate receptor subunits, and, based on Western blot analyses, is selective for the $\delta$ subunits in rat brain. The specificity of the antibody allowed characterization of the $\delta 1$ and $\delta 2$ subunits through immunoprecipitation, Western blotting, and im- 

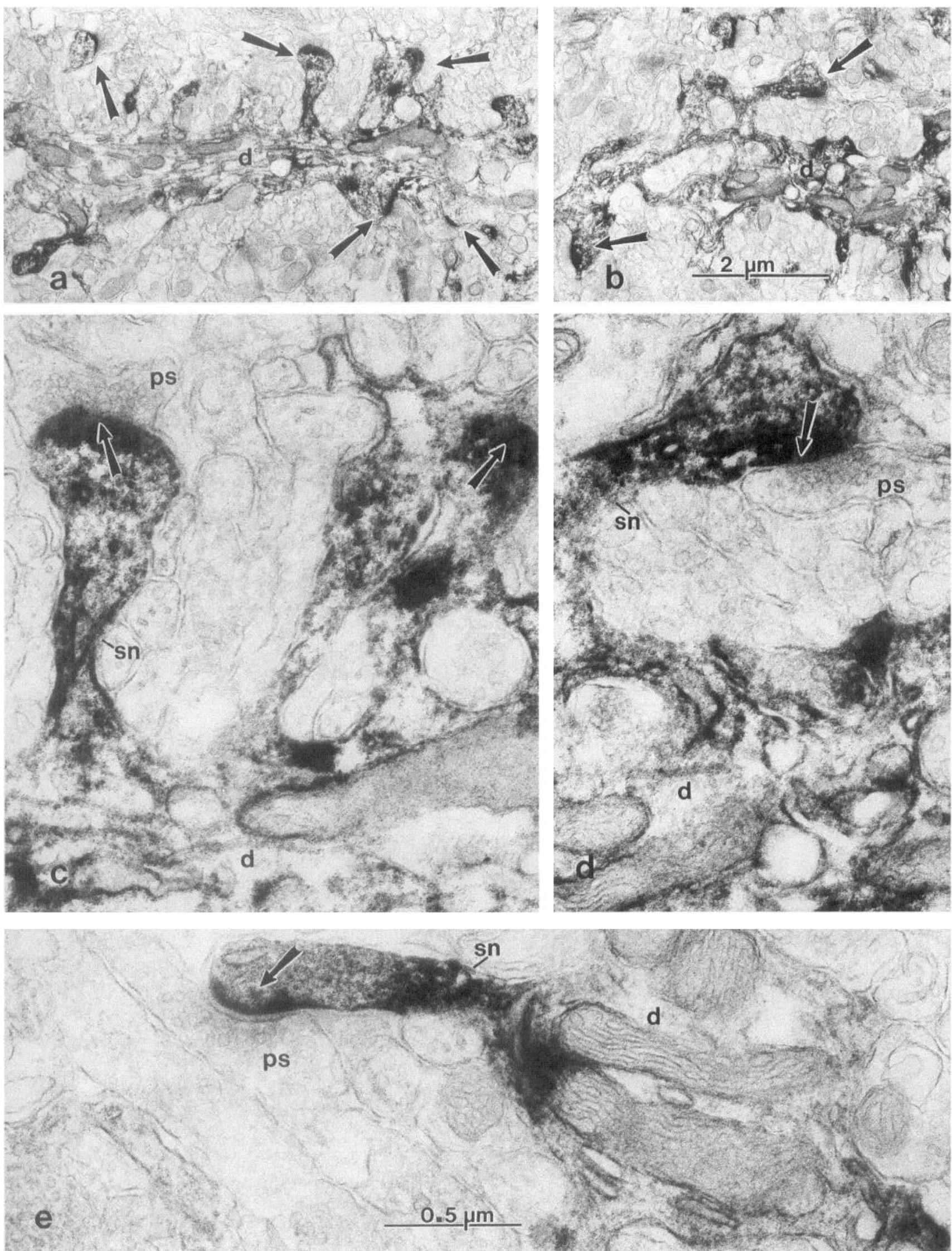

Figure 9. Electron micrographs of cerebellar molecular layer immunolabeled with antibody to $\delta 1 / 2 . d$, Main dendritic shaft; $s n$, spine neck; $p s$, presumptive parallel fiber presynaptic terminal; arrows, stained postsynaptic densities. $c$ and $d$ are high magnifications of $a$ and $b$, respectively. Compare dendrite spines and stained postsynaptic densities in Figure 9, $a$ and $c$, with possible corresponding structures from a similar section, seen with light microscopy (Fig. 8c) $a-d$, Upper molecular layer. $e$, Upper/middle molecular layer. Magnification: $a$ and $b, 12,500 \times ; c-e, 50,000 \times$. 
munocytochemistry. From these studies, the following major findings become apparent. First, based on immunoprecipitation analyses, the $\delta$ subunits do not appear to be associated with AMPA, kainate, NMDA, or mGluR $1 \alpha$ receptor subunits. Second, immunoprecipitation of the $\delta$ subunits does not immunoprecipitate ${ }^{3} \mathrm{H}$-AMPA, ${ }^{3} \mathrm{H}$-kainate, or ${ }^{3} \mathrm{H}$-glutamate binding activity from Triton X-100 solubilized cerebellar membranes suggesting that the $\delta$ receptor complex does not bind these ligands. Third, immunocytochemical analyses show intense immunostaining on the postsynaptic membrane of the parallel fiber/Purkinje spine synapse, characteristic of a postsynaptic receptor. These findings support the conclusion that the $\delta$ subunits form a unique postsynaptic receptor complex that is not associated with AMPA, kainate, or NMDA receptors.

\section{Relationship of $\delta$ subunits to other glutamate receptors}

The $\delta$ subunits do not form functional ion channels when expressed in transfected cells or oocytes (Yamazaki et al., 1992; Araki et al., 1993; Lomeli et al., 1993) suggesting that additional subunits are required for activity. The possibility that the $\delta$ subunits may assemble with subunits of other glutamate receptor subtypes was investigated by immunoprecipitation of detergent solubilized cerebellar membranes with the anti- $\delta 1 / 2$ antibody and staining for coimmunoprecipitating subunits. Coimmunoprecipitation of subunits of AMPA, kainate, NMDA, and metabotropic receptors was tested. We found that none of the subunits coimmunoprecipitated with the $\delta$ subunits indicating that complexes between $\delta$ and other subtypes are not formed. However, we cannot rule out the possibility of subunit dissociation during solubilization, although this approach is used commonly to determine subunit interactions and has been successfully applied to analyze structures of AMPA (Wenthold et al., 1992), kainate (Wenthold et al., 1994), and NMDA (Sheng et al., 1994) receptors. These findings are consistent with those of Lomeli et al. (1993) who investigated the physiological properties of cells cotransfected with cDNAs of $\delta$ subunits and AMPA, kainate, and NMDA receptor subunits, and found no evidence for interaction between the subunits. The lack of coimmunoprecipitation with known glutamate receptor subunits suggests that the $\delta$ subunits may form a complex with yet unidentified proteins. Immunoprecipitation of detergent-solubilized cerebellar membranes did not identify prominent copurifying proteins, as determined by silver staining, although several minor bands are present and these are candidates for further study. It is possible that $\delta 1$ and $\delta 2$ together form a functional receptor, but this is unlikely based on their very different distribution and developmental patterns (Araki et al., 1993; Lomeli et al., 1993).

\section{$\delta$ Subunits and ligand binding}

Ligand binding autoradiography on the cerebellum identified the predominant excitatory amino acid binding site in the Purkinje cell and molecular layers as a quisqualate-sensitive glutamate site (Greenamyre et al., 1984, 1985; Olson et al., 1987; Young and Fagg, 1990). This site is significantly reduced in number in mice lacking Purkinje cells, while in mice whose granule cell population was depleted, the number of quisqualate-sensitive sites is more than doubled, suggesting that this site is primarily restricted to the Purkinje cells (Olson et al., 1987). Because of the heavy expression of mGluR1 in Purkinje cells (Masu et al., 1991; Martin et al., 1992) and the fact that glutamate binding to mGluR1 is quisqualate-sensitive (Aramori and Nakanishi, 1992), most of the glutamate binding in the molecular layer of the cer- ebellum is likely to represent metabotropic receptors. Therefore, these results give little information concerning the ligand binding properties of the $\delta$. In the present study, we find that anti$81 / 2$ antibodies do not immunoprecipitate ${ }^{3} \mathrm{H}$-AMPA, ${ }^{3} \mathrm{H}$-kainate, or ${ }^{3} \mathrm{H}$-glutamate binding activity from Triton $\mathrm{X}-100$ solubilized cerebellar membranes. We cannot rule out the possibility that either solubilization or binding conditions were inappropriate for the $\delta$ receptor, although conditions of solubilization, immunoprecipitation, and binding were similar to those which have been used successfully for both AMPA and kainate receptors (Wenthold et al., 1992, 1994). These results are consistent with those of Lomeli et al. (1993) who showed that cells transfected with $\delta 1$ or $\delta 2 \mathrm{cDNAs}$ did not exhibit ${ }^{3} \mathrm{H}$-AMPA or ${ }^{3} \mathrm{H}$-kainate binding. The absence of binding activity in transfected cells could be explained if a critical component of the receptor complex was not expressed with the subunit; however, immunoprecipitation of the detergent solubilized receptor complex from brain would likely contain the total receptor complex. The fact that glutamate and glutamate-related ligands do not bind to the $\delta$ receptor may indicate that the $\delta$ receptor has a pharmacology unlike that of the known glutamate receptors and raises the question of whether or not glutamate is the natural agonist of the $\delta$ receptor. The postsynaptic localization of $\delta$ at parallel fiber/Purkinje spine synapses suggests that the parallel fiber neurotransmitter is the natural agonist of the $\delta$ receptor, and there is considerable evidence that this is glutamate, based on physiological studies (Stone, 1979; Crepel et al., 1982; Katno and Kato, 1987; Kano et al., 1988), granule cell lesion studies (Young et al., 1974; Sandoval and Cotman, 1978), and immunocytochemical localization of glutamate in the presynaptic terminal (Somogyi et al., 1986). Furthermore, mGluR1 $\alpha$ also has a postsynaptic localization at this synapse and glutamate is believed to be the natural agonist for this receptor (Martin et al., 1992).

\section{Immunocytochemical distribution of the $\delta$ subunits}

Light microscope distribution of $\delta 1 / 2$ immunoreactivity is consistent with a pattern resulting from the combined localization of $\delta 1$ and $\delta 2$ subunits. Thus, the light to moderate immunostaining seen in the cerebral cortex, hippocampus, and caudate/putamen may correspond to the localization of mRNA to $\delta 1$ (Lomeli et al., 1993; see also Fig. 12 of Tölle et al., 1993), while the dense staining in the Purkinje cells probably reflects the presence of abundant 82 , as shown previously by in situ hybridization (Araki et al., 1993; Lomeli et al., 1993) and light microscope immunocytochemistry (Araki et al., 1993). However, immunostaining in some structures may reflect the presence of both $\delta 1$ and $\delta 2$, including the gray matter of the spinal cord, periaqueductal gray, and possibly some portions of the cerebral corlex and hippocampus, as suggested by in situ hybridization studies (Lomeli et al., 1993; Tölle et al., 1993).

The data presented in this study, in conjunction with that of previous studies, indicate that glutamate receptors containing $\delta$ subunits and metabotropic receptors form the two major types of glutamate receptors in the parallel fiber/Purkinje spine synapse (assuming that the $\delta$ subunits form functional glutamate receptors). Electron microscope immunocytochemistry indicates that $\delta$ (this study) and mGluR1 $\alpha$ (Martin et al., 1992; Görcs et al., 1993) subunits are very abundant in the postsynaptic densities of parallel fiber/Purkinje spine synapses. GluR1 also is present at this synapse (Baude et al., 1994; but see Martin et al., 1993), although other glutamate receptor types may be absent 
or less common (GluR2-4: Martin et al., 1992, 1993, KA2; GluR6/7: Petralia et al., 1994c; NMDAR1 and 2: Petralia et al., 1994a,b). Use of postembedding immunogold techniques indicates that mGluR $1 \alpha$ may preferentially localize at the parallel fiber synapse periphery, while GluR $2 / 3 / 4 \mathrm{c}$ is chiefly distributed over the main body of the synaptic zone (Baude et al., 1993; Nusser et al., 1994); it should be interesting to see if future immunogold studies reveal a preferential localization of $\delta$ to subregions of this synapse. In addition, the great increase in abundance of both $\delta 1 / 2$ and mGluR $1 \alpha$ immunoreactivity, in immunoblots of the cerebellum at $15 \mathrm{~d}$ postnatal, matches: (1) the time of development of most parallel fiber/Purkinje spine synapses (Altman, 1972, 1982), (2) the time when sensitivity of Purkinje cells to glutamate more than doubles (review by Crepel and Audinat, 1991), and (3) the peak of metabotropic glutamate receptor-coupled activity in rat cerebellum (Mayat et al., 1994). However, since $\delta 1 / 2$ immunoreactivity also was common in many glial elements in the cerebellum, we cannot rule out that some of this increase seen at $15 \mathrm{~d}$ may represent immunolabeling of glia, since glial processes also increase in number at about this time (Altman, 1972).

\section{Physiological significance}

It is yet unclear how the $\delta$ receptor fits into the synaptic function of the Purkinje cell. Electrophysiological studies support the presence of non-NMDA receptors at the parallel fiber/Purkinje spine synapse and the involvement of AMPA receptors in longterm depression (LTD; reviews by Crepel and Audinat, 1991; Linden et al., 1991; Linden, 1994). However, it is not clear which AMPA subunits are present in the postsynaptic membrane of the parallel fiber/Purkinje spine synapse. Immunostaining with antibody to GluR2/3 is very light or absent at the postsynaptic side of the parallel fiber/Purkinje spine synapse (Martin et al., 1992, 1993), while staining of the Purkinje cell body is very intense (Petralia and Wenthold, 1992; Martin et al., 1993). In contrast, a study by Baude et al. (1994) reported that GluR1, which has a very low expression in Purkinje cells based on immunocytochemical and in situ hybridization studies (Petralia and Wenthold, 1992; Martin et al., 1993; Sato et al., 1993), has a significant expression at this synapse. In fact, excepting mGluR $1 \alpha, \delta$ is the only known glutamate receptor subunit which is expressed densely in both Purkinje cell bodies and parallel fiber/Purkinje spine synapses. Since our immunoprecipitation results do not support an association with AMPA receptors, we suggest that a $\delta$ subunit forms part of a unique non-NMDA receptor complex which is heavily expressed at this synapse, is intimately involved in LTD, and contains one or more, as yet, undiscovered subunits, as suggested by others (Araki et al., 1993; Lomeli et al., 1993).

\section{References}

Altman J (1972) Postnatal development of the cerebellar cortex in the rat. II. Phases in the maturation of Purkinje cells and of the molecular layer. J Comp Neurol 145:399-464.

Altman J (1982) Morphological development of the rat cerebellum and some of its mechanisms. In: The cerebellum-new vistas (Palay SL, Chan-Palay V, eds), pp 8-53. Berlin: Springer.

Amaral DG (1978) A Golgi study of cell types in the hilar region of the hippocampus in the rat. J Comp Neurol 182:851-914.

Araki K, Meguro H, Kushiya E, Takayama C, Inoue Y, Mishina M (1993) Selective expression of the glutamate receptor channel $\delta 2$ subunit in cerebellar Purkinje cells. Biochem Biophys Res Commun 197:1267-1276.

Aramori I, Nakanishi S (1992) Signal transduction and pharmacolog- ical characteristics of a metabotropic glutamate receptor, mGluR1, in transfected CHO cells. Neuron 8:757-765.

Baude A, Nusser Z, Roberts JDB, Mulvihill E, Jeffrey McIlhinney RA, Somogyi P (1993) The metabotropic glutamate receptor (mGluR1 $\alpha$ ) is concentrated at perisynaptic membrane of neuronal subpopulations as detected by immunogold reaction. Neuron 11:771-787.

Baude A, Molnàr E, Latawiec D, Jeffrey McIlhinney RA, Somogyi P (1994) Synaptic and nonsynaptic localization of the GluR1 subunit of the AMPA-type excitatory amino acid receptor in the rat cerebellum. J Neurosci 11:2830 2843 .

Bettler B, Boulter J, Hermans-Borgmeyer I, O'Shea-Greenfield A, Deneris ES, Moll C, Borgmeyer U, Hollmann M, Heinemann S (1990) Cloning of a novel glutamate receptor subunit, GluR5: expression in the nervous system during development. Neuron 5:583-595.

Boulter J, Hollmann J, O' Shea-Greenfield A, Hartley M, Deneris E, Maron C, Heinemann S (1990) Molecular cloning and functional expression of glutamate receptor subunit genes. Science 249:10331037.

Crepel F, Audinat E (1991) Excitatory amino acid receptors of cerebellar Purkinje cells: development and plasticity. Prog Biophys Mol Biol 55:31-16.

Crepel F, Dhanjal SS, Sears TA (1982) Effect of glutamate, aspartate and related derivatives on cerebellar Purkinje cell dendrites in the rat: an in vitro study. J Physiol (Lond) 329:297-317.

Egebjerg J, Bettler B, Hermans-Borgmeyer I, Heinemann S (1991) Cloning of a cDNA for a glutamate receptor subunit activated by kainate but not AMPA. Nature 351:745-748.

Gallo V, Patneau DK, Mayer ML, Vaccarino FM (1994) Excitatory amino acid receptors in glial progenitor cells: molecular and functional properties. Glia 11:94-101.

Giulian G, Moss RL, Greaser M (1983) Improved methodology for analysis and quantitation of proteins on onc dimensional silverstained slab gels. Anal Biochem 129:277-287.

Görcs TJ, Penke B, Bóti Z, Katarova Z, Hámori J (1993) Immunohistochemical visualization of a metabotropic glutamate receptor. Neuroreport 4:283-286.

Greenamyre JT, Young AB, Penney JB (1984) Quantitative autoradiographic distribution of $\mathrm{L}-\left[{ }^{3} \mathrm{H}\right]$ glutamate-binding sites in rat central nervous system. J Neurosci 4:2133-2144.

Greenamyre JT, Olson IMM, Penney IR, Young AB (1985) Autoradiographic characterization of $N$-methyl-D-aspartate-, quisqualateand kainate-sensitive glutamate binding sites. J Pharmacol Exp Ther 233:254-263.

Gregor P, Mano I, Maoz I, McKeown M, Teichberg VI (1989) Molecular structure of the chick cerebellar kainate binding subunit of a putative glutamate receptor. Nature 342:689-692.

Hampson DR, Huie D, Wenthold RJ (1987) Solubilization of kainic acid binding sites from rat brain. $J$ Neurochem 49:1209-1215.

Herb A, Burnashev N, Werner P, Sakmann B, Wisden W, Seeburg PH (1992) The KA-2 subunit of excitatory amino acid receptors shows widespread expression in brain and forms ion channels with distantly related subunits. Neuron 8:775-785.

Hollmann M, Heinemann S (1994) Cloned glutamate receptors. Annu Rev Neurosci 17:31-108.

Hollmann M, O'Shea-Greenfield A, Rogers SW, Heinemann S (1989) Cloning by functional expression of the glutamate receptor family. Nature 342:643-648.

Hunter C, Wheaton KD, Wenthold RJ (1990) Solubilization and partial purification of $\alpha$-amino-3-hydroxy-5-methyl-4-isoxazolepropionic acid binding sites from rat brain. J Neurochem 54:118-125.

Kano M, Kato M (1987) Quisqualate receptors are specifically involved in cerebellar synaptic plasticity. Nature 325:276-279.

Kano M, Kato M, Chang HS (1988) The glutamate receptor subtype mediating parallel fibre-Purkinje cell transmission in rabbit cerebellar cortex. Neurosci Res 5:325-337.

Keinänen K, Wisden W, Sommer B, Werner P, Herb A, Verdoorn TA, Sakmann B, Seeburg PH (1990) A family of AMPA-selective glutamate receptors. Science 249:556-560.

Kutsuwada T, Kashiwabushi N, Mori H, Sakimura K, Kushiya E, Araki K, Meguro H, Masaki H, Kumanishi T, Arakawa M, Mishina M (1992) Molecular diversity of the NMDA receptor channel. Nature 358:36-41.

Laemmli UK (1970) Cleavage of structural proteins during the assernbly of the head bacteriophage T4. Nature 227:680-685. 
Linden DJ (1994) Long-term synaptic depression in the mammalian brain. Neuron 12:457-472.

Linden DJ, Dickinson MH, Smeyne M, Connor JA (1991) A long-term depression of AMPA currents in cultured cerebellar Purkinje neurons. Neuron 7:81-89.

Lomeli H, Wisden W, Kohler M, Keinänen K, Sommer B, Seeburg PH (1992) High-affinity kainate and domoate receptors in rat brain. FEBS Lett 307:139-143.

Lomeli H, Sprengel R, Laurie DJ, Kohr G, Herb A, Seeburg PH, Wisden W (1993) The rat $\delta 1$ and $\delta 2$ subunits extend the excitatory amino acid receptor family. FEBS Lett $315: 318-322$.

Martin LJ, Blackstone CD, Huganir RL, Price DL (1992) Cellular localization of a metabotropic glutamate receptor in rat brain. Neuron 9:259-270.

Martin LJ, Blackstone CD, Levey AI, Huganir RL, Price DL (1993) AMPA glutamate receptor subunits are differentially distributed in rat brain. Neuroscience 53:327-358.

Masu M, Tanahe Y, Tsuchida K, Shigemoto R, Nakanishi S (1991) Sequence and expression of a metabotropic glutamate receptor. Nature 349:760-765.

Mayat E, Lcbrun F, Sassetti I, Recasens M (1994) Ontogenesis of quisqualate-associated phosphoinositide metabolism in various regions of the rat nervous system. Int J Dev Neurosci 12:1-17.

Meguro H, Mori H, Araki K, Kushiya E, Kutsuwada T, Yamazaki M, Kumanishi T, Arakawa M, Sakimura K, Mishina M (1992) Functional characterization of a heteromeric NMDA receptor channel expressed from cloned cDNAs. Nature 357:70-74.

Monaghan DT, Bridges RJ, Cotman CW (1989) The excitatory amino acid receptors: their classes, pharmacology, and distinct properties in the function of the central nervous system. Annu Rev Pharmacol Toxicol 29:365-402.

Monyer H, Sprengel R, Schoepfer R, Herb A, Higuchi M, Lomeli H, Burnashev N, Sakmann B, Seeburg PH (1992) Heteromeric NMDA receptors-molecular and functional distinction of subtypes. Science 256:1217-1221.

Mugnaini E (1972) The histology and cytology of the cerebellar cortex. In: The comparative anatomy and histology of the cerebellum: the human cerebellum, cerebellar connections, and cerebellar cortex (Larsell O, Jansen J, eds), pp 201-251. Minneapolis: University of Minnesota.

Nakanishi N, Shneider NA, Axel R (1990) A family of glutamate receptor genes: evidence for the formation of heteromultimeric receptors with distinct channel properties. Ncuron 5:569-581.

Nakanishi S (1992) Molecular diversity of glutamate receptors and implications for brain function. Science 258:597-603.

Nusser Z, Mulvihill E, Streit P, Somogyi P (1994) Subsynaptic segregation of metabotropic and ionotropic glutamate receptors as revealed by immunogold localization. Neuroscience 61:421-427.

Olson JMM, Greenamyre JT, Penney JB, Young AB (1987) Autoradiographic localization of cerebellar excitatory amino acid binding sites in the mouse. Neuroscience 22:913-923.

Palay SL, Chan-Palay V (1974) Cerebellar cortex: cytology and organization. New York: Springer.

Paxinos G, Watson C (1986) The rat brain in stereotaxic coordinates, $2 \mathrm{~d}$ ed. New York: Academic.

Peters A, Palay SL, Webster HF (1991) The fine structure of the nervous system, 3d ed. New York: Oxford UP.

Petralia RS, Wenthold RJ (1992) Light and electron immunocytochemical localization of AMPA-selective glutamate receptors in the rat brain. J Comp Neurol 318:329-354.

Petralia RS, Yokotani N, Wenthold RJ (1994a) Light and electron microscopic distribution of the NMDA receptor subunit, NMDAR 1 , in the rat nervous system using a selective antipeptide antibody. $J$ Neurosci 14:667-696.

Petralia RS, Wang Y-X, Wenthold RJ (1994b) The NMDA receptor subunits, NR2A and NR2B, show histological and ultrastructural localization patterns similar to those of NR1. J Neurosci 14:6102-6120.

Petralia RS, Wang Y-X, Wenthold RJ (1994c) Histological and ultrastructural localization of the kainate receptor subunits, KA2 and GluR6/7, in the rat nervous system using selective anti-peptide antibodies. J Comp Neurol 349:85-110.

Ribak CE, Seress L (1983) Five types of basket cell in the hippocampal dentate gyrus: a combined Golgi and electron microscope study. J Neurocytol 12:577-597.
Ryo Y, Miyawaki A, Furuichi T, Mikoshiba K (1993) Expression of the metabotropic glutamate receptor mGluR $1 \alpha$ and the ionotropic glutamate receptor GluR1 in the brain during the postnatal development of normal mouse and in the cerebellum from mutant mice. $J$ Neurosci Res 36:19-32.

Sakimura K, Bujo H, Kushiya E, Araki K, Yamazaki M, Yamazaki M, Meguro H, Warashina A, Numa S, Mishina M (1990) Functional expression from cloned cDNAs of glutamate receptor species responsive to kainate and quisqualate. FEBS Lett 272:73-80.

Sakimura K, Morita T, Kushiya E, Mishina M (1992) Primary structure and expression of the $\gamma 2$ subunit of the glutamate receptor channel selective for kainate. Neuron 8:267-274.

Sandoval ME, Cotman CW (1978) Evaluation of glutamate as a neurotransmitter of cerebellar parallel fibers. Neuroscience 3:199-206.

Sato K, Kiyama H, Tohyama M (1993) The differential expression patterns of messenger RNAs encoding non- $N$-methyl-D-aspartate glutamate receptor subunits (GluR1-4) in the rat brain. Neuroscience 52: 515-539.

Sheng M, Cummings J, Roldan LA, Jan YN, Jan LY (1994) Changing subunit composition of heteromeric NMDA receptors during development of rat cortex. Nature 368:144 147.

Shigemoto R, Nakanishi S, Mizuno N (1992) Distribution of the messenger RNA for a metabotropic glutamate receptor (mGluR1) in the central nervous system - an in situ hybridization study in adult and developing rat. J Comp Neurol 322:121-135.

Sommer B, Seeburg PH (1992) Glutamate receptor channels: novel properties and new clones. Trends Pharmacol Sci 13:291-296.

Somogyi P, Halasy K, Somogyi J, Storm-Mathisen J, Ottersen OP (1986) Quantification of immunogold labelling reveals enrichment of glutamate in mossy and parallel fibre terminals in cat cerebellum. Neuroscience 19:1045-1050.

Stone TW (1979) Glutamate as the neurotransmitter of cerebellar granule cells in the rat. Br J Pharmacol 66:291-296.

Tachibana M, Wenthold RJ, Morioka H, Petralia RS (1994) Light and electron microscopic immunocytochemical localization of AMPA-selective glutamate receptors in the rat spinal cord. J Comp Neurol 344: 431-454.

Tanabe Y, Nomura A, Masu M, Shigemoto R, Mizuno N, Nakanishi S (1993) Signal transduction, pharmacological properties, and expression patterns of two rat metabotropic receptors, mGluR3 and mGluR4. J Neurosci 13:1372-1378.

Tölle TR, Berthele A, Zieglgänsberger W, Seeburg PH, Wisden W (1993) The differential expression of 16 NMDA and non-NMDA receptor subunits in the rat spinal cord and in periaqueductal gray. $\mathbf{J}$ Neurosci 13:5009-5028.

Towbin H, Staehelin T, Gordon J (1979) Electrophoretic transfer of proteins from polyacrylamide gels to nitrocellulose sheets: procedure and some applications. Proc Natl Acad Sci USA 76:4350-4354.

Uchihori Y, Puro DG (1993) Glutamate as a neuron-to-glia signal for mitogenesis: role of glial $N$-methyl-D-aspartate receptors. Brain Res 613:212-220

Wada K, Dechesne CJ, Shimasaki S, King RG, Kusano K, Buonanno A, Hampson DR, Banner C, Wenthold RJ, Nakatani Y (1989) Sequence and expression of a frog brain complementary DNA encoding a kainate-binding protein. Nature 342:684-690.

Watkins JC, Krogsgaard-Larsen P, Honoré T (1990) Structure-activity relationships in the development of excitatory amino acid receptor agonists and competitive antagonists. Trends Pharmacol Sci 11:2533.

Wenthold RJ, Hunter C, Wada K, Dechesne CJ (1990) Antibodies to a C-terminal peptide of the rat brain glutamate receptor subunit, GluR-A, recognize a subpopulation of AMPA binding sites but not kainate sites. FEBS Lett 276:147-150.

Wenthold RJ, Yokotani N, Doi K, Wada K (1992) Immunochemical characterization of the non-NMDA glutamate receptor subunit-spccific antibodies: evidence for a hetero-oligomeric structure in rat brain. J Biol Chem 267:501-507.

Wenthold RJ, Trumpy VA, Zhu W-S, Petralia RS (1994) Biochemical and assembly properties of GluR6 and KA2, two members of the kainate receptor family, determined with subunit-specific antibodies. J Biol Chem 269:1332-1339.

Werner P, Voigt M, Keinänen K, Wisden W, Seeburg PH (1991) Cloning of a putative high-affinity kainate receptor expressed predominantly in hippocampal CA3 cells. Nature 351:742-744. 
Yamazaki M, Araki K, Shibata A, Mishina M (1992) Molecular cloning of a cDNA cncoding a novel member of the mouse glutamate receptor channel family. Biochem Biophys Res Commun 183:886892.

Young AB, Fagg G (1990) Excitatory amino acid receptors in the brain: membrane binding and receptor autoradiographic approaches. Trends Pharmacol Sci 11:126-133.

Young AB, Oster-Granite ML, Herndon RM, Snyder SH (1974) Glu'tamic acid: selective depletion by viral induced granule cell loss in hamster cerebellum. Brain Res 73:1-13. 